\title{
GOLD PENDANTS \\ FROM KRANJ AND KOPER (SLOVENIA)
}

\author{
Gojko Tica \\ Planina 45 \\ SI - 6232 Planina \\ tica.sistem@gmail.com
}

UDK / UDC: 904:671.121.9(497.4)"652/653"

Izvorni znanstveni rad / Original scientific paper

https://doi.org/10.52064/vamz.54.1.5

In this paper I discuss two gold pendants, from the Late Antique or Early Mediaeval Period, which are somewhat unique finds for Slovenian territory. The first pendant is from the Late Antique site of Kranj-Lajh (Carnium); it is leaf-shaped, and the chronologically older pendant of the two. The child grave in which this pendant was found is interpreted as belonging to an individual of the local Late Antique elite. The grave is notable also because some of the grave goods were made in the middle of the $5^{\text {th }}$ century $A D$, even though the burial presumably dates to the first half of the $6^{\text {th }}$ century $A D$. On the basis of a single-sided comb with low han-

\section{Key words:}

Kranj, Koper, Pannonian basin, Crimea, Late Antiquity, Early Mediaeval Period, pendants, earrings

\section{The leaf-shaped pendant of type Gáva ${ }^{1}$ from Grave 12/2009 at the site of Kranj-Lajh}

Lajh, in modern-day Kranj, Slovenia, is one of the largest Late Antique or Early Mediaeval cemeteries in the territory spanning the Eastern Alps and the Middle Danube region. It was continuously in use from the end of the $5^{\text {th }}$ century $A D$ and during the majority of the $6^{\text {th }}$ century AD. Prolonged fieldwork at the site, conducted during separate excavations within a span of over a dle, I assume that the individual did not belong to the Gothic cultural milieu. The second pendant, a tear-shaped specimen, was found in one of the oldest settlement layers of Early Mediaeval Koper (lustinopolis), at the site of Kapucinski vrt. I argue that it was worn not as a pendant on a necklace or earring, but rather as an integral part of an earring. This interpretation is based on earrings from another time (the second half of the $3^{\text {rd }}$ century $A D$ and the $4^{\text {th }}$ century $A D$ ) and place (south-western Crimea), with which the pendant from Koper shares many features.

hundred years, has yielded at least 720 graves, but it is estimated that more than 800 burials have in fact been discovered. Since 1982, 150 graves have been excavated, while the rest were ex plored at the end of the $19^{\text {th }}$ century and the beginning of the $20^{\text {th }}$ century AD. ${ }^{2}$ Rescue and revision excavations, which took place in 2009 and 2010, have yielded 92 new graves. ${ }^{3}$ For now,

\footnotetext{
I would like to express my sincerest gratitude to Dr Željko Demo for the time and effort he devoted to providing me invaluable advice and help during the writing of my PhD thesis, titled "Goths between the Adriatic Sea and Pannonia."

The pendant from Gáva is no longer the sole example of its kind; several morphologically and technologically similar objects have been discovered since, and it is thus justified to classify them together into a type named after the site of discovery of the first known specimen.
}

Knific Lux 2010, 31-32; 2015, 31. For the history of research at the site of Kranj-Lajh, see Lux, Ravnik 2008; for the history of research at the end of the $19^{\text {th }}$ century and the beginning of the $20^{\text {th }}$ century, see also: Bras Kernel 2002; for the excavations in 2009 and 2010, see the report of Urek et al. 2016. Vida Stare published artefacts known at the end of the $19^{\text {th }}$ century and the beginning of the $20^{\text {th }}$ century as a monograph (1980), but it needs revision due to several mistakes (Tica 2017, 288-291; 356-364), which have also been pointed out by several other authors (e.g. Bóna 1981; Knific 1995; Bras Kernel 2002).

$3 \quad$ Urek et al. 2016, 109. 


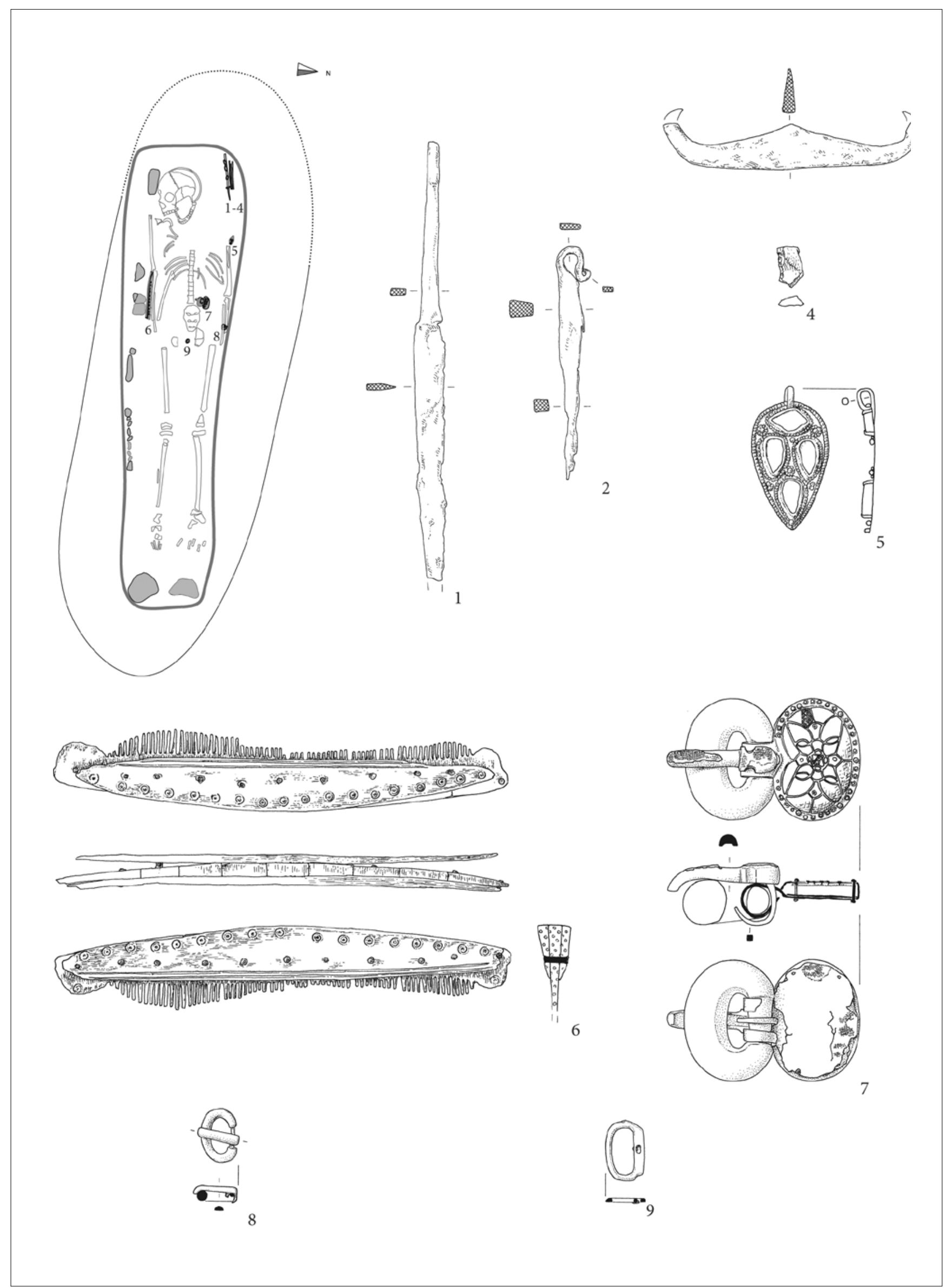

FIGURE 1. Kranj-Lajh, Grave 12/2009, Kranj-Lajh (Urek et al. 2016, PI. 86; 87: 7-9). 


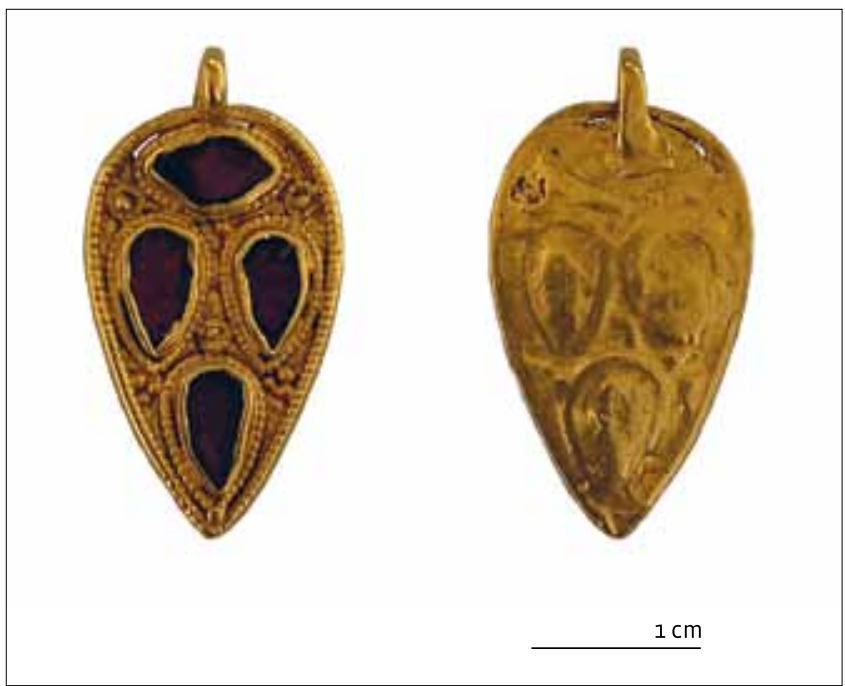

FIGURE 2. The pendant from Grave $12 / 2009$ (photo by G. Tica, with permission of the Gorenjski muzej).

the majority of the results remain unpublished, with the exception of a preliminary report ${ }^{4}$ and a few finds presented at an exhibition and published in the corresponding catalogue, both titled "Jewellery Remains Forever. Heritage, Our Most Precious Jewellery." ${ }^{5}$ The leaf-shaped pendant ${ }^{6}$ I am discussing is from Grave 12/2009, which emerged during the 2009 - 2010 excavations and was also one of the objects featured in the aforementioned catalogue and exhibition (Fig. 1).?

The grave in which the pendant was found, amongst other grave goods, belonged to a child (infans $I I, 11$ years). ${ }^{8}$ The pendant was positioned above the child's left shoulder. The leaf-shaped object is made of gold in the so-called "polychrome style" and measures $2.9 \times 1.6 \mathrm{~cm}$ (Fig. 2). The central motif consists of four raised, collared settings for four flat garnets, three tear-shaped and one oval. The pendant is suspended from a simple bail attached just under the top of the pendant, reaching over the filigree edge which encircles the entire pendant at the front. At the bottom right the edge is doubled due to a fold in the metal on the back of the pendant, which seems to be the result of an attempt make the edge of the pendant look uniform. The raised collars for the garnets are enclosed by a wire that imitates granulation and complements a small flower, with grains and clusters, crafted in granulation technique and positioned between the garnets and on the outer part of the pendant.

The pendant could be included in the relatively small and morphologically inconsistent group of leaf-shaped gold pendants that are known from the period between the first half or middle

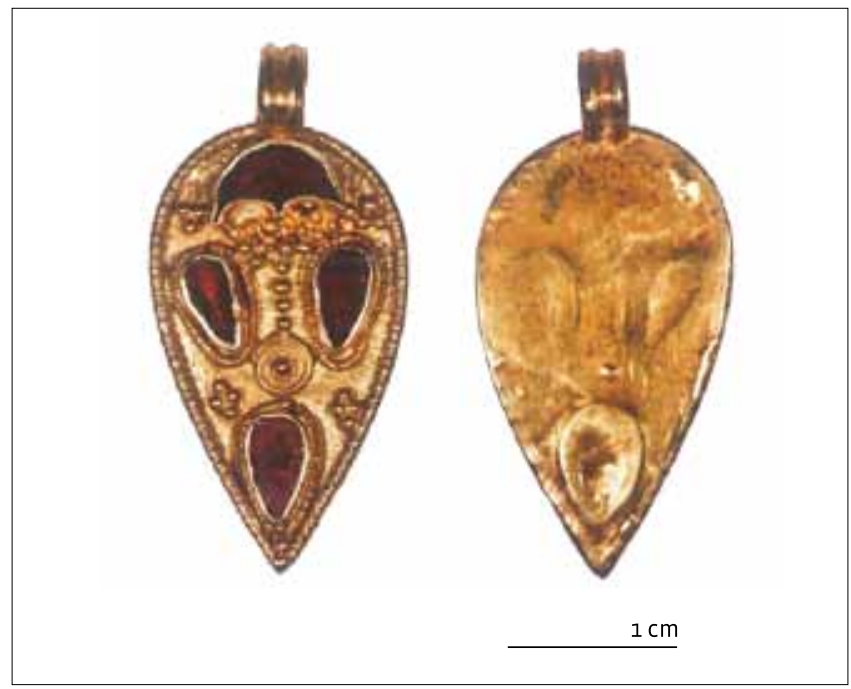

FIGURE 3. Pendant from Gáva (Horváth, Bendő, May 2013, Fig. 1: e).

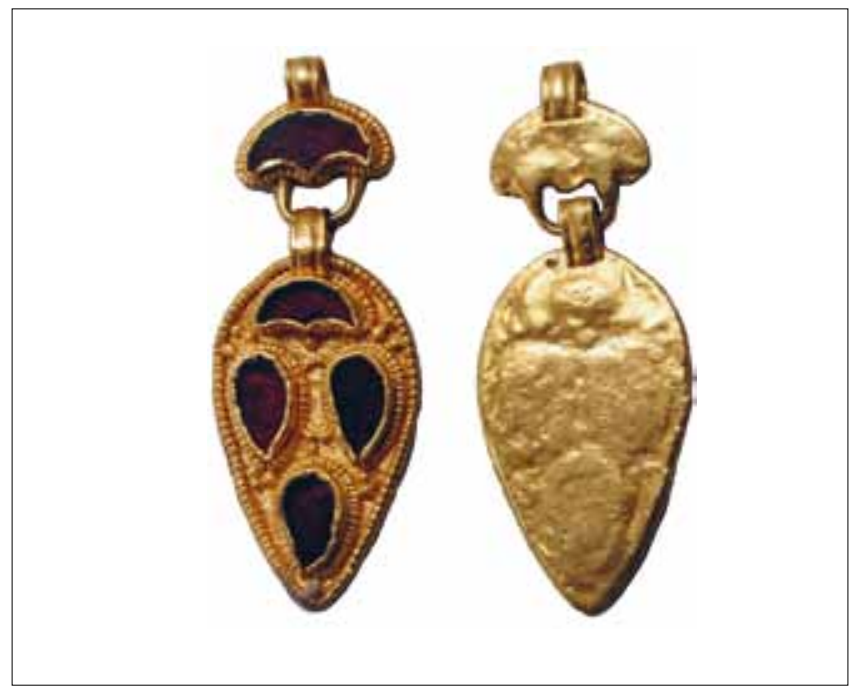

FIGURE 4. One of the pendants from Florești (archive of the Muzeul Național de Istorie a Transilvaniei).

of the $5^{\text {th }}$ century AD and the transition from the $6^{\text {th }}$ to the $7^{\text {th }}$ century $A D$ in the territory between the Caucasus and the Danube basin. ${ }^{9}$ The westernmost specimens of leaf-shaped pendants were found as far off as Mérida in south-western Spain, where they were unearthed in Grave no. 2 and were part of a necklace. ${ }^{10}$ Stemming from the first half of the $5^{\text {th }}$ century $A D$, they are presumed to be part of the so-called Pontic-Danubian attire brought

\footnotetext{
$4 \quad$ Urek et al. 2016

Full title in Slovenian: Najdbe, ki so ponesle ime Kranja v svet, in Perko, V. (ed.), Nakit ostane. Dediščina, naš najdragocenejši nakit. Arheološki nakit iz Beograda, Tolmina, Brežic, Kranja in Kopra. Tatu, najbolj osebna oblika nakita, Gorenjski muzej, 2019, 85-119.

6 In the exhibition catalogue (Perko 2018, 111, cat. no. 26) the pendant was described as zlat obesek kapljičaste oblike ("gold, tear-shaped pendant").

$7 \quad$ Urek et al. 2016, 132, 236, cat. no.59, PI. 86: 5; Perko 2018, 111, cat. no. 26.

$8 \quad$ Urek et al. 2016, 131-132, cat. no. 59, 60, PI. 86, PI. 87: 7-9.
} 


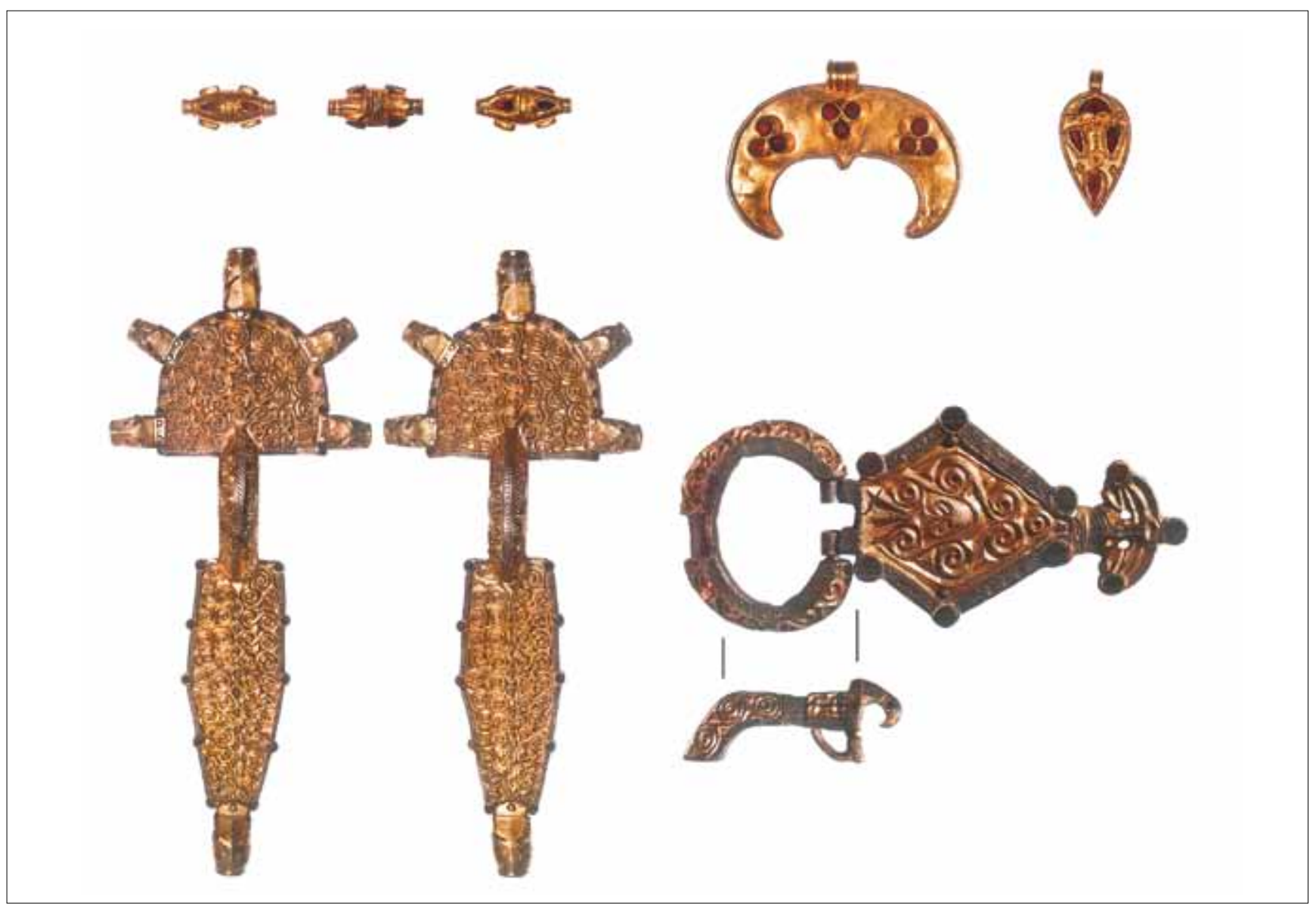

FIGURE 5. Several artefacts from Gáva (Horváth, Bendő, May 2013, Fig. 1; 2: a-b; 4: a-b).

to Spain by the Danubian Suebi. ${ }^{11}$ A relationship between finds of gold leaf-shaped pendants and the spread of the PonticDanubian attire in the Hunnic and post-Hunnic periods is also postulated by Anna Mastykova. ${ }^{12}$

The best parallels for the pendant from Kranj are a pendant from Gáva (Fig. 3), presently part of Gávavencsellő in north-eastern Hungary, and nine pendants from a 'princely grave' at the Polus Center in Florești, near Cluj-Napoca in Transylvania, Romania (Fig. 4). The pendants from Mérida and Gáva, along with a pendant from Kerch (Pantikápaion), in Crimea, from the BerthierDelagarde collection, ${ }^{13}$ have been recognised as the most lavish specimens of leaf-shaped pendants by Mastykova, who has classified them as the Mérida-Kerch-Gáva type. ${ }^{14}$
The leaf-shaped pendants listed are all made in the 'polychrome style', known for its sparkling appearance, achieved by encrusting gemstones or stones, usually red in colour, such as garnets, or small pieces of coloured glass in a gold base. The specimens discussed fall into the category of polychrome objects with a visible golden base, where the raised, collared settings containing flat or convex-cut tops are spread apart. They are similar in style to the second group of polychrome Hunnic-period jewellery as defined by Irina Zasetskaia, which includes polychrome bow brooches characterised by semicircular heads, rhombic feet, and also gold granulae. In both brooches and pendants, the arrangement of the inserts follows the shape of the object. Brooches of this type are found in the $5^{\text {th }}$ century AD, possibly also the $6^{\text {th }}$, in Western and Central Europe as well as Crimea. ${ }^{15}$ On

\footnotetext{
11 Heras Mora, Olmedo Gragera 2015, 284-286 (ethnic identity of finds from Mérida), Fig. 15.7 (pendants).

12 Mastykova 2018, 152

13 Andrási 2008, 37-38, cat. no. 11, PI. 6: 11, Colour PI. 3: 11. The pendant, made in the cloisonné technique, has been dated to the second half of the $5^{\text {th }}$ century $A D$ on the basis of morphological similarities with the pendant from Gáva (Aibabin 2008, 143).

14 Mastykova 2018, 150-151, Fig. 8. It seems that Mastykova was, at the time of writing her paper, unaware of the pendants from Florești.
}

15 In the Middle Danube basin they are present in the D2 stage (Untersiebenbrunn group), i.e. in the first half of the $5^{\text {th }}$ century AD (Bierbrauer 1995, 560, 562; Tejral 1997, 335). Some authors argue that objects (not limited to brooches) in the 'polychrome style' with a visible golden base are typical of the Hunnic and post-Hunnic horizon of the $5^{\text {th }}$ century AD. The objects are supposed to have been transmitted from the territory around the Black Sea to the West by the Huns and associated peoples, predominantly Germanic in origin (e.g. Vinski 1970, 146-147). 


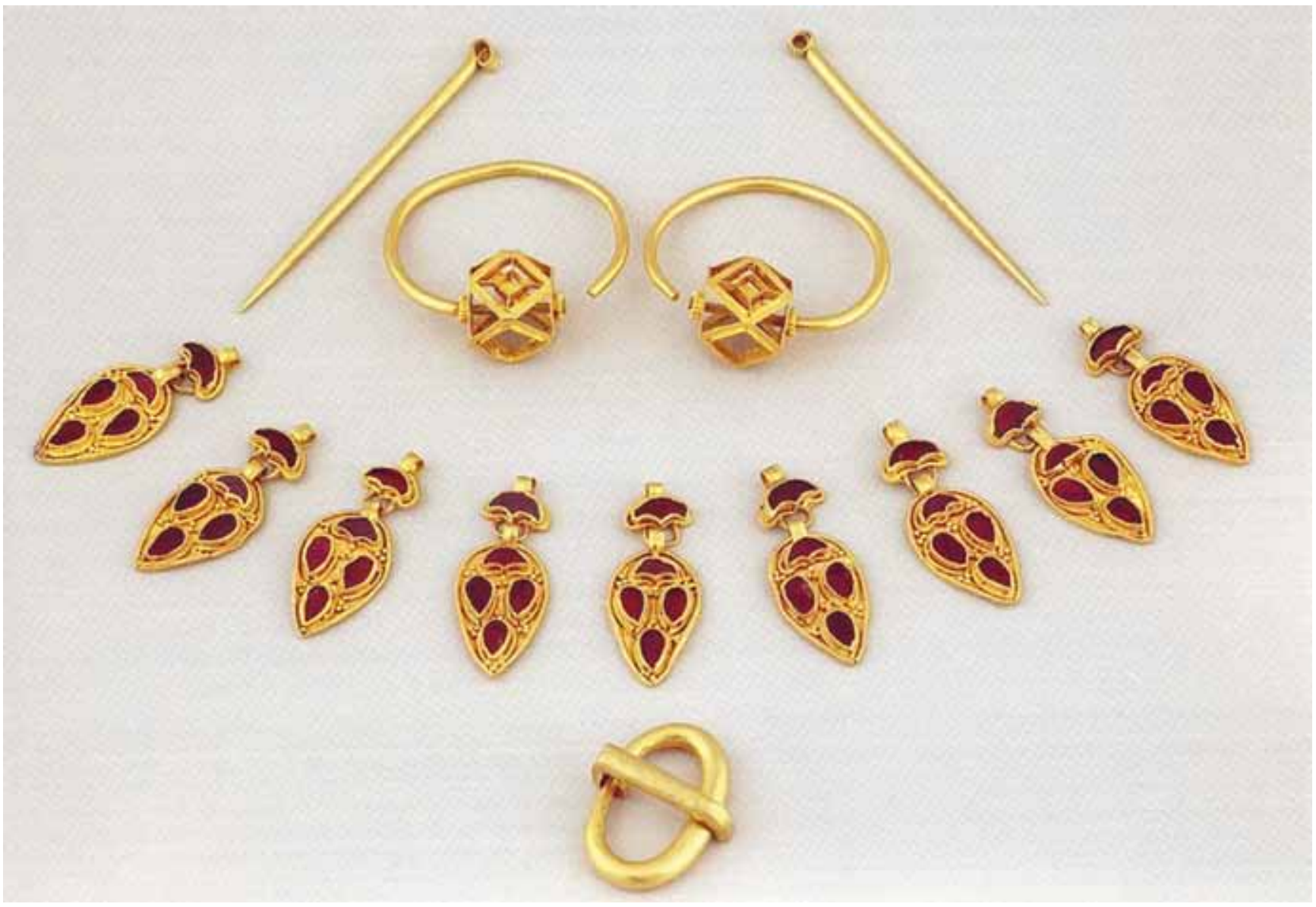

FIGURE 6. Gold finds from a rich female grave in Florești (archive of the Muzeul Național de Istorie a Transilvaniei).

the other hand, they are unknown from the steppes of Southern Russian and Ukraine, where indeed the polychrome decoration technique with granulation was not generally used during this period. Zasetskaia therefore argues that this style of decoration is Germanic in origin and was, as such, unknown to the equestrian peoples of these steppes. ${ }^{16}$ Alexander Aibabin argues that the Huns conquered Crimea after first having crossed the Middle Danube basin, ${ }^{17}$ which could mean that the polychrome brooches from the Middle Danube basin are in fact older than the Crimean ones. Most current researchers trace the tradition of applying granular decorations to the Black Sea and Mediterranean area of the Hellenistic period, ${ }^{18}$ while the "polychrome style" could have spread westwards not only from the Black Sea via the Pannonian basin, but also from the Eastern Mediterranean. ${ }^{19}$
Let us focus again on the best parallels to the pendants from Kranj, Gáva and Florești. The finds from Gáva have been published several times due to the prominent pair of brooches and the belt buckle of the so-called Karavukovo type. ${ }^{20}$ These objects are part of a larger assemblage of finds that were excavated in 1910 (Fig. 5).

Several items were stolen or otherwise ruined, and although the preserved documentation contains no mention of skeletal remains, it is likely that the whole assemblage came from the same lavishly furnished female grave. ${ }^{21}$ Apart from the pendant, a pair of bow brooches decorated in chip-carving (Kerbschnitt), a belt buckle, parts of a necklace with three gold beads and garnet inserts, three amber beads, a crescent-shaped gold pendant
16 Zasetskaia 1994, 74-75, Fig. 14. It should be noted that polychrome objects classified by the author as Types 1 and 3 are rather similar; both types are, according to Zasetskaia, associated with "equestrian cultures" (i.e. the Huns) However, contexts involving objects of Types 1 and 3 are characterised by a complete absence of polychrome bow brooches with semicircular heads and rhombic feet, which in turn are precisely the objects listed by Zasetskaia as the sole members of her Type 2. (For the 'polychrome style' of the Hunnic period, see ibid., 68-75)

17 Aibabin 2008, 142 .

18 See e.g. Treister 2004. For theories of origin of the "polychrome style" (“barbarian”, classical Graeco-Roman, or Eastern Persian) see: e.g. Zasetskaia
1994, 72-75; Adams 2000, 13-14, n. 1-7; Horváth 2013, 281-283, Fig. 7, 8 and their bibliographies.

19 Horváth 2013, Fig. 8

20 Initially published by Jósa 1910, Fig. 6-11; Hampel 1911, Fig. V: 6; the entire group of objects was furthermore published in Almássy, Istvánovits, Kurucz (eds.) 1997, 60-73, Pls 3: 2; 4; one of the most recent publications is Rácz, Koncz 2015, 402, cat. no. VII.7; for further reading see: Horváth, Bendő, May 2013, 251, n. 4.

21 Horváth, Bendő, May 2013, 251, 254 
and silver toiletry items are preserved. The artefacts from this Gáva assemblage are crafted in the "polychrome style" with a visible golden base. They have few direct parallels, all of which, however, date to the Hunnic period or to the third quarter of the $5^{\text {th }}$ century $A D$, i.e. to the immediately post-Hunnic period. ${ }^{22}$ The belt buckle features a depiction of a human head on a rhomboid fitting. It is made in the Karavukovo style, characterised by densely chip-carved spiral vine ornaments. ${ }^{23}$ Such belt buckles came into fashion in the second third of the $5^{\text {th }}$ century AD. The finest specimens, mostly dating to the third quarter of the $5^{\text {th }}$ century $A D$, are usually found in the burials of the social elites of the post-Hunnic period. ${ }^{24}$ The level of craftsmanship involved in producing these items is perhaps best exemplified by a pair of cast silver gilded brooches which are over $30 \mathrm{~cm}$ long and together weigh almost $1 \mathrm{~kg}$. They are decorated with a dense interweave of small chip-carved spirals. ${ }^{25}$ Dating to the middle of the $5^{\text {th }}$ century $A D$, the pair are also among the earlier artefacts of their kind. ${ }^{26}$ As noted by Eszter Horváth, Zsolt Bendő and Zoltán May, the brooches and belt buckle show signs of prolonged wear, pointing to a significant gap between the time they were made and the time they were deposited in the presumed grave. ${ }^{27}$ Last but not least, the assemblage contains a silver-alloy toiletry set. Although similar sets started appearing in graves of the first half of the $5^{\text {th }}$ century $A D$ (e.g. at Untersiebenbrunn), ${ }^{28}$ the majority of such finds come from Eastern Germanic female graves in the Danube basin from the middle of the $5^{\text {th }}$ century onwards, usually including tweezers. ${ }^{29}$

Approximately 170 graves from the Migration period were excavated in 2006 and 2007 before construction work for a new mall, Polus Center, in Florești, near Cluj-Napoca, Romania. ${ }^{30}$ The grave of a younger female individual stood out for the lavishness of the funerary attire. The grave was also positioned at a distance from the other graves. The preserved grave goods consist of a pair of gold earrings with a hollow polyhedron, nine leaf-shaped pendants, a pair of gold pins with a spiral head supposedly in lieu of brooches, an oval gold belt buckle, a two-sided horn comb and an amber bead (Fig 6.). ${ }^{31}$

Gold earrings with a hollow polyhedron containing (or having contained) garnets are typical finds from the late $4^{\text {th }}$ century $A D$ and the $5^{\text {th }}$, especially the second half, in the Pannonian basin as well as eastern-Crimean Kerch. They appear sporadically at the beginning of the $6^{\text {th }}$ century $A D$, as well. ${ }^{32}$ Simple oval belt buckles, whether of iron, copper alloy, silver or gold, are widespread between the Caspian Sea and Central Europe during the entire $5^{\text {th }}$ century $A D$ and at the beginning of the $6^{\text {th }}$ century $A D .^{33}$ The pins from Florești are unique for their spiral heads. Pairs of pins with variously shaped heads (polyhedron, flat spiral, spade, head of a bird of prey, and flat head) are found in graves from the $4^{\text {th }}$ and $5^{\text {th }}$ centuries $A D$, but only rarely. The majority are known from the Middle Danube basin, from the Roman Late Antique provinces of Valeria and Pannonia Prima. A couple of specimens come from the Barbaricum just across the Danube, appearing up to Transylvania and Moldova in the East, but also up to North Africa, Spain and the Atlantic coast in the West. ${ }^{34} \mathrm{~A}$ pair of pins could replace a pair of brooches on a peplos-style garment, which is usually considered part of the Pannonian dress. Even though this style of garment is usually associated with Eastern Germanic or Barbaric groups, Joan Pinar and Gisele Ripoll argue that it actually derives from the Roman tradition and that it should not be automatically associated with "barbaric newcomers." 35 Pins could also be used for fastening diadems or necklaces, as is demonstrated by a find from Beiral in north-western Portugal. ${ }^{36}$ Based on the facts that graves with pairs of pins are rare, and that such graves typically feature other high-value pieces of attire and jewellery, it has been hypothesised that the graves belong to female members of local elites, be it in the Middle Danube basin, in Northern Africa, on the Iberian Peninsula or in Barbaricum. ${ }^{37}$ Pairs of pins were used as grave goods in the first three quarters of the $5^{\text {th }}$ century AD. ${ }^{38}$ Specimens from Barbaricum were possibly made slightly later than those from the Roman provinces, stemming from approximately the middle to the second half of the $5^{\text {th }}$ century AD. ${ }^{39}$ The supposed grave at Gáva, as well as the one at Florești, could thus be interpreted as graves of members of the post-Hunnic, possibly Gepid, social elite of the second half of the $5^{\text {th }}$ century AD. ${ }^{40}$

Even though the pendants from Kranj, Gáva and Florești are undoubtedly of the same type, there are still differences between them. The top garnet is crescent-shaped in the Gáva and Florești pendants, while Kranj's has an oval garnet. The cross section of the bail is circular at the front and flat at the back in the pendant from Kranj, while the other two have more or less ribbon-
22 For parallels (sites of Florești, Oradea, Someșeni and Kerch) and further reading, see: Horváth, Bendő, May 2013, 275-277.

23 For more on the Karavukovo style, see: e.g. Vinski 1962

24 E.g. Tejral 2012, 118.

25 Horváth, Bendő, May 2013, 256, 280, Fig. 8, 9

26 For more on dating the brooches to the middle or third quarter of the $5^{\text {th }}$ century AD, see: e.g. Bierbrauer 1995, 575; Tejral 2011, 189; Horváth, Bendő, May 2013, 256

27 Horváth, Bendő, May 2013, 254-256. Although the signs of wear are more pronounced on the belt buckle and brooches, other pieces of jewellery, such as both pendants and gold alloy beads, also display them to a lesser degree.

28 For Untersiebenbrunn see Kubitschek 1911, PIs 5: 7, 8. Slightly older are the toiletry sets from the shores of the Black Sea (Tejral 2011, 165-166).

29 Tejral 2011, 166.

30 See: Lăzărescu 2019, 81-83 with cited bibliography for the partially-published cemetery.

31 Nagy, Rotea 2010; Nagy, Rotea 2014; Lăzărescu 2019, 95-99.
32 Harhoiu 1997, 60-62; Andrási 2008, 35; Bărbulescu 2008, 54-56; Eger et al. 2017, 118; Lăzărescu 2019, 96.

33 Harhoiu 1997, 106-107. For gold specimens, see: Calligaro et al. 2000, 133, cat. no. 16.5, 16.6, 149, cat. no. 21.4, 169, cat. no. 27.13, 27.14.

34 Quast 2005, Fig. 26; Pinar, Ripoll 2008, Fig. 11.

35 For graves with pairs of pins and their distribution in the graves of the $5^{\text {th }}$ century AD, see: Quast 2005, 263-270; Pinar, Ripoll 2008, 112-116; basic information also available in: Lăzărescu 2019, 97-99.

36 Arezes 2017, 77

37 Pinar, Ripoll 2008, 114. For pairs of pins, see also: Quast 2005, 263-271.

38 The oldest specimens from Late Antique burials in Roman Pannonia could be dated to the end of the $4^{\text {th }}$ century AD (Quast 2005, 264).

39 Quast 2005, 264-270; Pinar, Ripoll 2008, 112-113.

40 Gáva (Horváth, Bendő, May 2013, 251), Florești (Nagy, Rotea 2010, 230; 2014, 638; Lăzărescu 2019, 101-102). 
shaped bails. Another difference is in the ornament adorning the space between the garnets. The simplest one is from Florești, with three small spherical granules. The Gáva ornament is more lavish, with spherical granules between and around the inserted garnets, as well as a spiral with a small sphere in the centre. The Kranj specimen has three small spheres above the lower garnet, a small sphere under the top, oval garnet, and three flower-shaped forms crafted in the granulation and filigree techniques, arranged in a triangle between the top and bottom leaf-shaped garnets. The outer front rims of the pendants from Gáva and Florești are of a better, more precise make than in the Kranj pendant. The Florești and Kranj specimens have in common a net decoration on the gold foil (poillon) set under the garnets, while the Gáva specimen has plain foil. All three specimens have a sphere at the bottom tip of the pendant. While the specimens from Kranj and Gáva ${ }^{41}$ were the only objects of their kind in their respective (in Gáva presumed) graves, the Florești grave contained nine pendants, probably forming part of a necklace or a garment in the bust area of a dress. Additionally, they hung on a small crescent-shaped pendant, itself adorned with garnet in the same manner, with a similarly ribbed outer rim, and a similar ribbon-shaped bail. In spite of the differences between the pendants from Gáva and Florești, archaeologists argue that they were produced by the same workshop. ${ }^{42}$ It is interesting to note, however, that the garnets from the Gáva pendant originate from Southern India or Sri Lanka, ${ }^{43}$ while the garnet from Florești could be of European origin, most likely from Dunkelsteinerwald or Zillertal, in Austria. ${ }^{4}$ If the pendants were in fact made in the same workshop, this would indicate that goldsmiths were employing raw materials from different sources. The garnets on the below-mentioned belt buckle from grave 12/2009 in Kranj also speak in favour of this assumption. Garnets from both Rajasthan, in India, and Sri Lanka or Southern India were used on the same fitting. ${ }^{45}$

To my knowledge, no archaeometric analysis has been done for the Kranj pendant, making a comparison with the Hungarian and Romanian specimens as of yet impossible. Similarly, in the absence of analyses it is impossible to determine whether the rim of the Kranj specimen had undergone later repairs, as the outer rim and the attachment of the bail would seem to suggest. For now it can only be established that the pendant was likely made in the middle of the $5^{\text {th }}$ century $A D^{46}$ somewhere in the Pannonian basin.

The dating of Grave 12/2009 in Kranj is based mostly on a belt buckle consisting of an oval loop and a kidney-shaped fitting

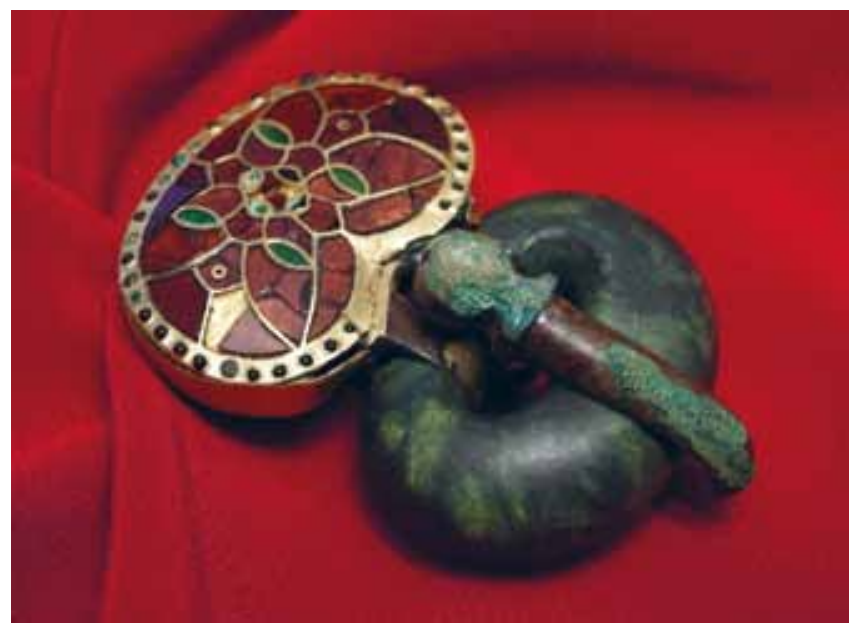

FIGURE 7. Belt buckle from Grave 12/2009, Kranj-Lajh (photo by L. Jaklič, with permission of the Gorenjski muzej).

(Fig. 7)..$^{47}$ The oval loop is made of stone, ${ }^{48}$ the copper-alloy prong has a shield-shaped base, and the kidney-shaped fitting is in polychrome. The prong is attached to the fitting with a strip of gilded copper alloy. The top of the fitting features flat oval garnets and green glass ovals. Thirty small, round red garnets are inserted into the gold rim of the fitting in five groups of six, intersected with rivets joining the decorated upper part of the fitting with the copper-alloy base. The 'polychrome style' of the fitting is different from that of the pendant, where the golden base is visible: the raised cells containing flat garnet and glass inserts cover the entire decorated area. For this decoration style the term cloisonné is frequently used. Belt buckles with kidney-shaped fittings in the cloisonné style were in use between the second half of the $5^{\text {th }}$ century AD and the beginning of the $6^{\text {th }}$ century AD. ${ }^{49}$ Belt buckles with loops made of stone, most frequently rock crystal (quartz) or sepiolite (meerschaum), and organic material, most frequently bone, have a wider timeframe of use, from the late $4^{\text {th }}$ century to the first half of the $6^{\text {th }}$ century AD, but their peak corresponds roughly to that of kidney-shaped and cloisonné belt buckles..$^{50}$ Most such belts were discovered in male graves in the Rhine, upper Danube, and Tisza basins: that is to say, areas predominantly settled or ruled by the Franks, Alemanni and Gepids. ${ }^{51}$ Belt buckles with stone loops are typically found in richly furnished graves, ${ }^{52}$ and are believed to have been given as diplomatic gifts or military service awards. ${ }^{53}$ There are solid
41 The pendant from Gáva originates from the context (if in fact it was only one context) of a presumed grave that was later destroyed. On this basis we may assume that this was the only pendant of this kind in the grave.

42 Stylistically and technologically (Horváth, Bendő, May 2013, 276; Lăzărescu 2019, 97).

43 Horváth, Bendő, May 2013, 263, 269, Fig. 2.

44 Fritsch et al. 2010, 317-318.

45 Šmit et al. 2014, 91; Pavlovič 2017, 74-75

46 This corresponds with the period in which the polychrome pendants with visible golden base from Gáva were made (Horváth, Bendő, May 2013, 256).
$47 \quad$ Urek et al. 2016, 132, 243-245, 59-60 (Catalogue and plates), PI. 87: 7; Perko 2018, 113, cat. no. 34

48 Interpreted as malachite (Perko 2018, 113, cat. no. 34) or Greek green por phyry (Urek et al. 2016, 243).

49 E.g. Quast 1993, 54; Harhoiu 1997, 112-115; Schulze-Dörrlamm 2009, 91-94

50 E.g. Bierbrauer 1975, 158-161; Quast 1996, 335-337; Eger et al. 2017, 221

51 Quast 1996, Fig. 7 (map of the distribution of belt buckles with quartz loops).

52 Quast 1993, 54

53 Quast 1996, 340-341. 
analogies for setting small garnets into entire rims of belt fittings, for example in the graves of Apahida, near Cluj-Napoca in Transylvania, ${ }^{54}$ as well as on the other side of Europe in the grave of Childeric I of the Salian Franks, at Tournai in Belgium. ${ }^{55}$ In Apahida, various cloisonné items feature the combination of red garnets and green glass seen in the belt fitting from Kranj. ${ }^{56}$

The graves at Apahida and the grave of Childeric I all count among some of the most richly furnished graves of the second half of the $5^{\text {th }}$ century AD in Europe. However, the belt buckle from Kranj can not be dated to the second half or the end of the $5^{\text {th }}$ century $A D$, as shield-based prongs only started appearing in the first half of the $6^{\text {th }}$ century $A D$, with the earliest small examples such as the one from Kranj stemming from between $A D 510$ and $530 . .^{57}$ Apart from analyses of garnets, ${ }^{58}$ the belt buckle from Kranj has not been archaeometrically analysed, and thus it cannot be excluded that the buckle had undergone repair and that the prong was added to the buckle later. This hypothesis is based on the damage of the gilded copper-alloy strip that connects the loop to the fitting, and on the state of preservation of the copper-alloy base of the belt buckle.

Last, but not least in importance, is the find of a single-sided comb with low handle that was positioned above the right ulna of the deceased (Fig. 1: 6). Combs with low bow- or triangleshaped handles appeared in Central Europe at the end of the $5^{\text {th }}$ century AD by the latest. They had probably been adopted by the Langobards in Bohemia and Moravia, and subsequently passed on to the Gepids in the Pannonian basin in the first half of the $6^{\text {th }}$ century AD. Interestingly enough, such combs were not found in any context that could in any way be associated with the Pannonian, Balkan or Apennine Goths. ${ }^{59}$

The leaf-shaped pendant and the belt buckle from Kranj's grave $12 / 2009$ could represent typical finds of the second half of the $5^{\text {th }}$ century $A D$, assuming that the shield-shaped prong was a later addition to the belt buckle, and knowing that the pendant could already have been made in the middle of the $5^{\text {th }}$ century AD. On the other hand, the shield-shaped prong - and probably the

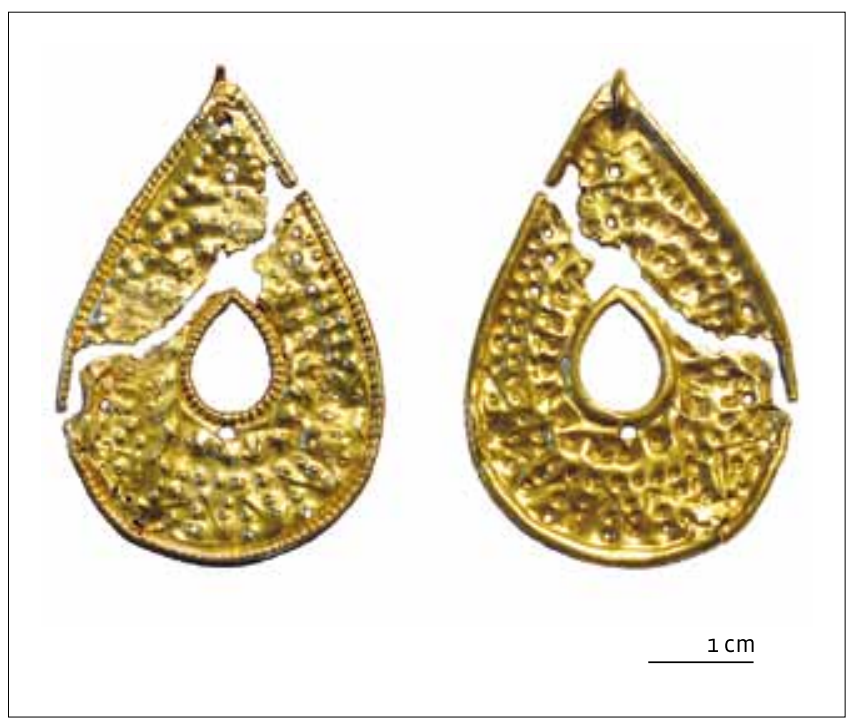

FIGURE 8. Pendant from Kapucinski vrt, Koper (photo by M. Sakara, with permission of the Pokrajinski muzej Koper).

single-sided comb with low handle - place the grave in the first half of the $6^{\text {th }}$ century AD, after the year 510 . The belt buckle and the pendant are doubtless items such as were only deposited in richly furnished graves; hence we can speculate that the grave belongs to a child from an elite family of Late Antique Carnium. Both finds are potentially part of a family heirloom that would have been made years, if not decades or half a century, before they were deposited. While establishing ethnic affiliation on the basis of grave goods is risky for the Late Antique period, especially for 'cosmopolitan' cemeteries such as Kranj-Lajh, I argue that, on the basis of the comb, the grave does not belong to a member of the Goths that lived in Carnium. As already mentioned, there is not a single context in which the connection between such a single-sided comb with low handle and the population of (Ostro) Goth settlements could be made between the $4^{\text {th }}$ and the middle of the $6^{\text {th }}$ century AD.
54 Oanță-Marghitu 2010, 223, cat. no. 40.c, 225, cat. no. 40.2; 2014, 159, left Fig., 160, right Fig., 162, right Fig., 164; Oanță-Marghitu, Nagy 2014, 617, cat. no. 167.1, 621 , cat. no. 167.2.1, 622, cat. no. 167.2.2, 167.2.3, 623, 167.2.4, 624, cat. no. 167.2.5, 625 , cat. no. $162.2 .7,167.2 .8$

55 Quast 2015, 167-168, Fig. 3, PI. 2: 1; 6: 1; 7: 1; 9; 10; 15: 3, 9, 11, 12, 14, 19; 16; 17; 18; 20; 21 .

56 Oanță-Marghitu 2010, 222, cat. no. 40.a, 223, cat. no. 40.b, 224, cat. no. 40.1; 2014, 161, left Fig., Oanță-Marghitu, Nagy 2014, 622, cat. no. 167.2.2, 626, cat. no. $167.2 .10,627,628$, cat. no. 167.2 .12

57 Koch 2001, 65-66, code Y24, Fig. 21: Y24; Slabe 2003, 85.

58 Fifteen garnets from the belt buckle were analysed: six were classified as type I, four as type II, and five as type III. Garnets of types I and II are predominantly almandines; the most likely origin of Type I garnets is Rajasthan, in NW India; type-III garnets are attributed to sites in Sri Lanka and South India, but many also originate from sites in Eastern Africa and Madagascar; precise location of type-II garnets in India is still disputed, although the authors propose that it is identical with that of type-III garnets (Šmit et al. 2014, 91, T. 2; for garnet types, see also: Calligaro et al. 2002).

59

Tica 2017, 300 


\section{Tear-shaped pendant from Kapucinski vrt, in Koper}

Preventive archaeological excavations took place in 1986 and 1987 in the city centre of Koper, more precisely in the gardens previously owned by the Order of Friars Minor Capuchin. Residential areas from Late Antiquity, and partly from the Early Byzantine $\left(5^{\text {th }}-7^{\text {th }} / 8^{\text {th }}\right.$ century $\left.A D\right)$ as well as from the Early Mediaeval Period $\left(7^{\text {th }}-8^{\text {th }} / 9^{\text {th }}\right.$ century AD) were discovered in the area.$^{60} \mathrm{~A}$ pendant was found in Room 28 of what is believed to be an Early Mediaeval building. The tear-shaped pendant is $4.9 \mathrm{~cm}$ long and $3 \mathrm{~cm}$ wide, is made of gold, and has a tear-shaped cut-out in the centre (Fig. 8). ${ }^{61}$

The outer rim of the pendant and the rim of the cut-out are reinforced with an attached wire which mimics the granulation on the face of the pendant. The bail was attached at the top of the pendant. At the time of discovery, the pendant was broken in two pieces and deformed at the rim. In the course of restoration work, the deformations were evened out and both halves glued together, but the bail was broken off the pendant and then incorrectly reattached to a small hole below the top of the pendant, somewhat lower than its original location. The decoration on the front of the pendant consists of zig-zag lines at the lower rim in repoussé technique, and similarly-made small holes, where the tool punched through the metal, which cover the entire pendant. At the top of the pendant, the holes form a small cross. ${ }^{62}$

Radovan Cunja has found a good parallel for the pendant in three tear-shaped gold pendants that are, together with glasspaste beads, part of a necklace from the Early Mediaeval site of Bruncu e S'Olia, at Dolianova, Sardinia. ${ }^{63}$ Cunja argues that the similarities are expressed especially in the tear shape of the pendants, the reinforced and granulated rim, and the bail at the top of the pendant. All three pendants from Dolianova featured an inset central round glass cabochon surrounded by wire that mimics granulation. It is speculated that a similar cabochon was set in the pendant from Koper, as well. There are both differences and similarities between the three pendants from Dolianova and the one from Koper. The foremost is size. While I could not obtain the actual measurements of the Dolianova pendants, I can deduce from the available photographs that they are significantly smaller than the specimen from Koper. The surface of the Dolianova pendants is smooth, in contrast with the one from Koper, which has a relief decoration. The glass cabochons from the Sardinian specimens are small and round, while the one from Koper was presumably bigger and tear-shaped. Judging from the photographs, the rim around the raised collared setting of the Sardinian specimens is not decorated, while the setting of the Koper specimen is decorated with faux granulation.

\footnotetext{
$60 \quad$ Cunja 1989a; 1989b; 1991; 1996.

61 Cunja 1989a, 30, cat. no. 30; 1991, 46, cat. no. 29; 1996, 57-58, 142, PI. 1: 12, 39: 2; 2001, 37, cat. no. 100; 2018, 128, 135, cat. no. 3.

62 Description of the object based on Cunja 1996, 57-58, n. 85; 2018, 128

63 Taramelli 1919, Fig. 9; Serra 1976, PI. 13
}

Cunja's second parallel for the pendant under discussion comes from Ravenna, ${ }^{64}$ a specimen predominantly in teardrop shape and with a zigzag motif. ${ }^{65}$ But Ravenna's pendant differs from the one from Koper in that it was made by chisel cutting and has a gold plate inserted in the centre part, on which two human outlines and a cross above them are depicted. The Ravenna specimen comes from the $6^{\text {th }}$ or $7^{\text {th }}$ century AD.

Isabella Baldini Lippolis classified the pendant from Ravenna among the group of locally-made gold pendants in the shape of a small drop (Type 8$)^{66}$, which were being produced at the end of the $6^{\text {th }}$ century, and in the $7^{\text {th }}$, in Constantinople as well as in local workshops. ${ }^{67}$ The specimens vary in length from just under $2 \mathrm{~cm}$ to just under $6 \mathrm{~cm}$. At the same time, Baldini Lippolis emphasises that the pendants, especially those found individually, could have been worn either as pendants on necklaces or as pendants on earrings (Type 4 / Variant $f$ as defined by Baldini Lippolis). ${ }^{68}$ The centre of production for gold-alloy earrings with tear-shaped pendants at the end of the $6^{\text {th }}$ century $A D$, and in the first half of the $7^{\text {th }}$, was Constantinople. ${ }^{69}$

Let us focus again on the pendant from Koper. The fabrication of both the front and back faces, as well as the tear-shaped opening in the centre, indicate that the setting for the glass or stone insert was tear-shaped. The attached gold at the top of the pendant possibly indicates later tampering with the item, and the two small holes along a straight line from the top to the bottom of the pendant, on either side of the tear-shaped opening, ${ }^{70}$ seem to suggest that the pendant was different when it was first made. Originally, it could have been an integral part of an earring, and not necessarily a pendant for a necklace or earring. My hypothesis may be supported by other earrings, albeit from a different time and place.

The earrings in question are found mainly in south-western Crimea (Fig. 9). ${ }^{71}$

They consist of a metal plate with a small hole at one end and a wire hoop at the other, ending with a hook. Most specimens are made of silver, rarely gold. The tear-shaped metal plate is cov-

64 Minguzzi 1983, 198, no. 18.7; Baldini Lippolis 1999, 146, no. 7; 2006, 140, cat no. V.4; Cavallari 2005, 139, cat. no. 85

65 The pendant from Ravenna, measuring $1.8 \mathrm{~cm}$ in length and $2 \mathrm{~cm}$ in width, is also smaller than Koper's

66 Baldini Lippolis 1999, 146, cat. no. 7.

67 Baldini Lippolis 1999, 126, 145-146.

68 Baldini Lippolis 1999, 76, 96-97. Tear-shaped pendants that hung from earrings measure between approximately 2.5 and $6 \mathrm{~cm}$ in length, with the ma jority measuring approximately $4 \mathrm{~cm}$, and others approximately $5 \mathrm{~cm}$.

69 Baldini Lippolis 1999, 76.

70 The majority of the holes on the pendant probably came about with the gradual wear of the material in the indents of the metalwork decoration. The aforementioned lines of holes, however, can be interpreted as intentionally made. Another large hole in the same line, about half a centimetre under the top of the pendant, probably also resulted from the wear of the metal at the tip of the indentation. Had it been riveted, the metal would be bent concavely.

71 E.g. Khrapunov 2002, 50-51, Figs 103: 4, 5; 104: 5, 6; 108: 14, 16; 206: 19, 20; 2013, 50-51, Fig. 48: 1, 2; 2018, 139-140, Fig. 10: 1-3; Aibabin, Khairedinova 2017, 54-55, Figs 52: 3, 4; 55: 1-6, 10, 11, 14; Khrapunov, Stoyanova 2018. 


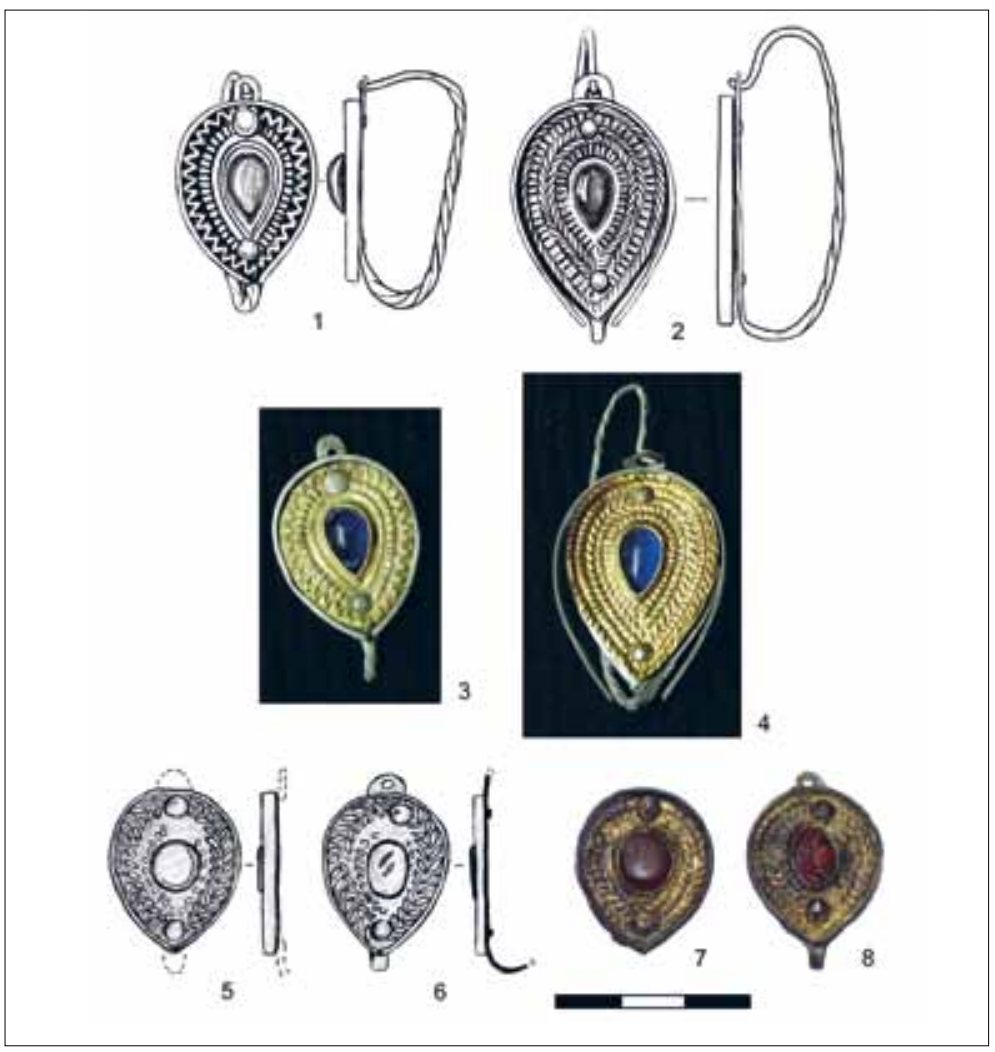

FIGURE 9. Earrings from Opushki cemetery; selection. (Khrapunov, Stoyanova 2018, Fig. 2: 1-8).

ered in gilded silver or gold foil, which is usually attached to the plate with two rivets. Earring plates usually have a tear-shaped (or, less frequently, oval) opening in the middle, into which pieces of glass or carnelian were inserted. The edges of the foils, as well as their surface, are decorated with zigzag lines forming a fishbone pattern and intersected with braids and similar ornaments. Earrings of the highest quality can feature filigree ornaments (Fig. 10); their plates are between $2.5 \mathrm{~cm}$ and a little less than $4 \mathrm{~cm}$ long. Similarly made, but slightly larger and oval in shape, are metal bracelet plates (Fig. 10).

The bracelets have a similar geographical and temporal distribution. ${ }^{72}$ Both earrings and bracelets of this type belong to the group of Late Antique polychrome items of the pre-Hunnic period, i.e. the second half of the $3^{\text {rd }}$ century AD and the $4^{\text {th }} .^{73}$ It is worth noticing that, in contrast with the Bosporan Kingdom and other parts of Crimea, the Northern Caucasus, the Lower Don basin, and the north-western shores of the Black Sea, where the Late Antique 'polychrome style' was used on weapons, belt sets and equestrian equipment, this style is only known from earrings, bracelets and sporadically other jewellery in the south-western part of Crimea, but not weapons and equestrian equipment. ${ }^{74} \mathrm{All}$ these polychrome objects are usually interpreted to have been produced by Bosporan craftsmen, on the basis of items from the Late Antique workshops along the Danube. ${ }^{75}$ One of the most impressive examples of the pre-Hunnic Late Antique polychrome craft is parade helmets of the Berkasovo type. ${ }^{76}$

Despite the differences in time and place, the pendant from Koper finds many similarities among the Crimean earrings. First and foremost is the shape, including the tear-shaped opening for the semiprecious stone or glass insert, although the techniques used to decorate the surface of the Koper pendant and the Crimean earrings are different. The pendant from Koper is also slightly bigger, although, as has been adduced above, earring pendants can also be bigger than the pendant from Koper. Moreover, if the holes on the Koper specimen are indeed a by-product of riveting, then the pendant had to be mounted on some sort of base, and it would thus be reasonable to assume that the manner of attaching the pendant to its base is similar to what is found in the Crimean earrings and bracelets. I cannot conclusively demonstrate that the specimen from Koper was, in fact, an integral part of an earring, but to the best of my knowledge, what I have listed are the best parallels for an object that is in its own way unique, and could well have been the pendant of an earring or a necklace, but not in the form in which it was unearthed.

\footnotetext{
72 E.g. Khrapunov 2002, 40, type II.

73 Yatsenko, Malashev 2000, 227-228; Khrapunov 2013a, 50-51; Khrapunov, Stoyanova 2018, 259-260.

74 Khrapunov 2013a, 51; Khrapunov, Stoyanova 2018, 259-261.
}

75 Ambroz 1989, 26-27; Aibabin 1999, 44; Aibabin, Khairedinova 2017, 55; Khrapunov, Stoyanova 2018, 259-260. Igor Khrapunov argues, based on the differences between the earrings (they seem to come in pairs), that they were produced as individual commissions and not in bulk (Khrapunov 2002, 51; Khrapunov, Stoyanova 2018, 260).

76 Manojlović-Marijanski 1964; Dautova-Ruševljan, Vujović 2011, 16-23; D’Amato, Negin 2017, 256-266. 
FIGURE 10. Two bracelets and a pair of earrings from the grave 24 in Droozhnoye (Khrapunov 2013b, Fig. 6).

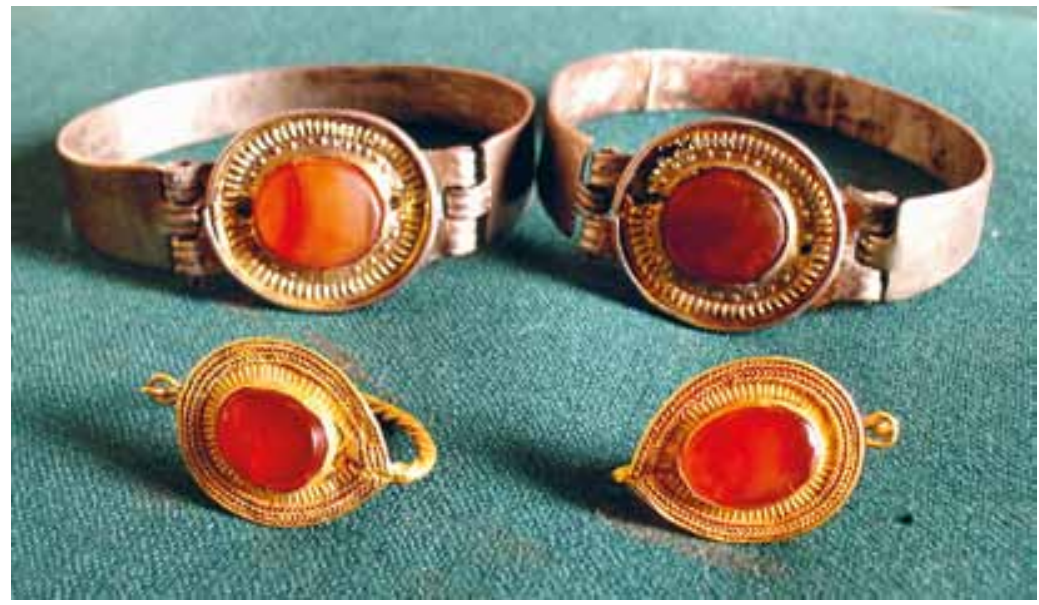

\section{Conclusion}

Both pendants under discussion are remarkable finds for the territory of modern-day Slovenia. They are the only leaf- and tearshaped pendants made of gold from the Late Antique or Early Mediaeval Period known in Slovenia. The specimen from Kranj belongs to what may be termed the Gáva type. It is the only known product from Slovenia that can be classified among polychrome objects with a visible golden base, due to the spacing between the raised collared settings for the individual garnets, and its production can be placed in the Hunnic or, more likely, post Hunnic period, in the $5^{\text {th }}$ century AD. It probably originates from one of the production centres in the Pannonian basin, possibly in Gepid territory, given the available parallels. Another interesting aspect of the pendant from Kranj is that it would have been a relic at the time of deposition; and, in conjunction with the belt buckle, it suggests that Grave $12 / 2009$ at Kranj-Lajh is the burial of a member of Late Antique Carnium's social elite, dating to the first half of the $6^{\text {th }}$ century AD.

The teardrop-shaped pendant from Koper was found in one of the buildings of the Early Mediaeval town. It is a unique object with currently only general parallels, in terms of both shape and handwork. In fact, only the basic shape has any parallels at all. This holds true especially for artefacts originating from the end of the $6^{\text {th }}$ century AD and the $7^{\text {th }}$. On the basis of the teardrop outline with a teardrop opening for an insert, and of the holes that could have facilitated fastening to some sort of base, we can draw parallels with earrings that were in use in the second half of the $3^{\text {rd }}$ century $A D$ and in the $4^{\text {th }}$ century AD in south-western Crimea. I would be reluctant to conclude that those Crimean specimens had directly influenced the pendant from Koper, especially due to chronological and geographical disparity, but they do offer an alternative possibility for interpreting the manner in which the specimen from Koper was worn.

\section{Acknowledgements}

I would like to express my gratitude to Verena Perko of the Gorenjski muzej, Kranj, for enabling me to access and take photographs of the pendant and belt buckle from Kranj, as well as for permission to use existing photographs; to Maša Sakara of the Pokrajinski muzej Koper, in Koper, for providing me with photographs of the pendant from Koper; to Mihai Rotea and Szabolcs Nagy of the Muzeul Național de Istorie a Transilvaniei, ClujNapoca, for providing me with photographs of the finds from Florești-Polus Center; to Igor' N. Khrapunov of the Tavricheskaya Academy of the Crimean Federal University named after V. I. Vernadsky (Таврическая академия. Крымский федеральный университет им. В. И. Вернадского) for providing me with illustrations and photographs of the Crimean earrings and bracelets; to Blaž Kumer and Rok Bremc of PJP d.o.o., Slovenska Bistrica, for their help with digital image editing; and, last but not least, I would like to thank the head of PJP d.o.o., Primož Predan.

Translated by Kaja Stemberger Flegar 


\section{BIBLIOGRAPHY}

Adams 2000 - N. Adams, The Development of Early Garnet Inlaid Ornaments, in Bálint, C. (ed.), Kontakte zwischen Iran, Byzant und Steppe im 6.-7. Jahrhundert, Varia Archaeologica Hungarica 10, 2000, 13-70.

Айбабин 1999 - А.И. Айбабин, Этническая история ранневизантийского Крыма, ДАР, 1999.

Aibabin 2008 - A. Aibabin, Commentary on Select Items and Groups in the Collection, in Andrási J. (ed.) with contributions by A. Aibabin and a scientific report by S. La Niece and M. Cowell, The Berthier-Delagarde Collection of Crimean Jewellery in the British Musem and Related Material, Research Publication 166, The British Museum, 2008, 141-149.

Айбабин, Хайрединова 2017 - А.И. Айбабин, э.А. Хайрединова, Крымские готы страны Дори (середина III - VII в.), Крым в истории, культуре и экономике России, Издательство Антиква, 2017.

Almássy, Istvánovits, Kurucz (eds.) 1997 - K. Almássy, E. Istvánovits, K. Kurucz (eds.), Das Gold von Nyíregyháza (archäologische Fundkomplexe mit Goldgegenständen in der Sammlung des Jósa-András-Museums Nyíregyháza), Archaologische Sammlungen in Nyíregyháza 1, 1997.

Амброз 1989 - А.К. Амброз, Хронология древностей Северного Кавказа V-VII вв., Москва "Наука", 1989

Andrási 2008 - J. Andrási, The Catalogue of the Collection, in J. Andrási, J. (ed.) with contributions by A. Aibabin and a scientific report by S. La Niece and $M$ Cowell, The Berthier-Delagarde Collection of Crimean Jewellery in the British Musem and Related Material, Research Publication 166, The British Museum, 2008, 33-114.

Arezes 2017 - A. Arezes, Colar o diadema de Beiral, in López Quiroga, J., Martínez Tejera M. (eds.), In Tempore sueborum. El tiempo de los suevos en la Gallaecia (411-585). El primer reino medieval de Occidente, Deputación Provincial de Ourense, $77-78$.

Baldini Lippolis 1999 - I. Baldini Lippolis, L'oreficeria nell'impero di Constantinopoli tra IV e VII secolo, Edipuglia, 1999.

Baldini Lippolis 2006 - I. Baldini Lippolis, Abbigliamento e simboli di rango, in Augenti, A., Bertelli, C. (eds.), Santi, banchieri re. Ravenna e Classe nel VI secolo. San Severo il tempio ritrovato, Skira, 2006, 134-147.

Bărbulescu 2008 - M. Bărbulescu, Mormântul princiar germanic de la Turda / Das germanische Fürstengrab von Turda, Universitatea Babeș-Bolyai ClujNapoca, Publicațiile institutului de studii clasice 10, Tribuna, 2008.

Bierbrauer 1975 - V. Bierbrauer, Die ostgotischen Grab- und Schatzfunde aus Italien, Biblioteca degli Studi medievali 7, Centro italiano di studi sull'alto medioevo, 1975

Bierbrauer 1995 - V. Bierbrauer, Das Frauengrab von Castelbolognese in der Romagna (Italien). Zur chronologischen und historischen Auswertbarkeit des ostgermanischen Fundstoffs des 5. Jahrhunderts in Südosteuropa und Italien, Jahrbuch des Römisch-Germanischen Zentralmuseums Mainz 38/2, 1995, 541592.

Bóna 1981 - I. Bóna, Vida Stare, Kranj. Nekropola iz časa preseljevanja ljudstev (s prispevkom Zdenko Vinski, Ovrednotenje grobnih pridatkov in István Kiszely, Antropološki predledi), Catalogi et Monographiae cura Musei Nationalis Labacensis editi 18. Ljubljana 1980, Archaeologiai Értesítő 108, 1981, 294-299.

Bras Kernel 2002 - H. Bras Kernel, Ženski grob z zlatim nakitom iz Lajha v Kranju unpublished MA thesis, Univerza v Ljubljani, Filozofska fakulteta, Oddelek za arheologijo, 2002.

Calligaro et al. 2000 - T. Calligaro, M. Kazanski, U. Koch, P. Périn, J. Tejral, F. Vallet, L'Or des princes barbares. Ve siècle après J.-C. - Catalogue de l'exposition, Musée des antiquités nationales, château de Saint-Germain-en-Laye, 26 septembre 2000-8 janvier 2001, Reiss-Museum, Mannheim, 11 février-4 juin 2001, Éditions de la Réunion des musèes nationaux, 2000.

Calligaro et al. 2002 - T.Calligaro, S.Colinart, J.-P. Poirot, C.Sudres, Combined external-beam PIXE and $\mu$-Raman characterisation of garnets used in Merovingian jewellery, Nuclear Instruments and Methods in Physics Research B/189, 2002, 320-327.
Cavallari 2005 - C. Cavallari, Oggetti di ornamento personale dall'Emilia Romagna bizantina. I contesti di rinvenimento, Studi e Scavi n. s. 13, Ante Quem, 2005

Cunja 1989a - R. Cunja, Koper med Rimom in Benetkami. Izkopavanja na vrtu kapucinskega samostana / Capodistria tra Roma e Venezia. Gli scavi ne convento dei Cappuccini, Medobčinski zavod za varstvo naravne in kulturne dediščine Piran / Instituto intercomunale per la tutela dei beni naturali e culturali Pirano, 1989

Cunja 1989b - R. Cunja, Arheološko izkopavanje na bivšem vrtu kapucinskega samostana v Kopru (1986-1987) / Gli scavi archeologici nell' ex orto del convento dei Cappuccini Capodistria (1986-1987), in Guštin, M. (ed.), Prispevki k zgodovini Kopra / Contributi per la storia di Capodistria, Pokrajinski muzej Koper / Museo Regionale di Capodsitria, 1991, 21-28.

Cunja 1991 - R. Cunja, Koper zwischen Rom und Venedig. / Capodistria tra Roma e Venezia, Regionalmuseum Koper / Museo Regionale di Capodsitria, 1991.

Cunja 1996 - R. Cunja, Poznorimski in zgodnjesrednjeveški Koper. Arheološko izkopavanje na bivšem Kapucinskem vrtu v letih 1986-1987 v luči drobnih najdb 5. do 9. stoletja / Capodistria tardoromana e altomedievale. Lo scavo archeologico nell'ex orto dei Cappuccini negli anni 1986-1987 alla luce dei reperti dal V al IX secolo d.C., Zgodovinsko društvo za južno Primorsko / Societàstorica del Litorale, Znanstveno raziskovalno središče Republike Slovenije, Koper / Centro de ricerche scientifische della Repubblica di Slovenia, Capodistria / Science and Research Centre of the Republic of Slovenia, Koper, Pokrajinski muzej Koper / Museo regionale di Capodsitria, 1996.

Cunja 2001 - R. Cunja, 100. Nakit in deli noše, in Bitenc, P., Knific, T. (eds.), Od Rimljanov do Slovanov. Predmeti, Narodni muzej Slovenije, 2001, 37.

Cunja 2018 - R. Cunja, Arheološki nakit iz Kopra in Predloke, in Perko, V. (ed.), Nakit ostane. Dediščina, naš najdragocenejši nakit. Arheološki nakit iz Beograda, Tolmina, Brežic, Kranja in Kopra. Tatu, najbolj osebna oblika nakita, Gorenjski muzej, 2019, 125-139.

D’Amato, Negin 2017 - R. D’Amato, A. E. Negin, Decorated Roman Armour. From the Age of the Kings to the Death of Justinian the Great, Frontline Books, 2017.

Dautova-Ruševljan, Vujović 2011 - V. Dautova-Ruševljan, M. Vujović, Kasnoantički šlem iz Jarka / Late Roman Helmet from Jarak, Muzej Vojvodine Novi Sad, 2011.

Eger et al. 2017 - H. Eger, G. Oepen-Domschky, F. Naumann-Steckner, M. Trier, Goldenes Zeitalter. 100 Meisterwerke der Völkerwanderungszeit, Hirmer, 2017.

Fritsch et al. 2010 - E. Fritsch, C. Ionescu, V. Simon, S. Nagy, K. Nagy-Póra, M. Rotea, 5th century garnet jewelry from Romania, Gems \& Gemology 46/4, Winter 2010. The Quarterly Journal of the Gemological Institute of America, 2010, 316-318

Hampel 1911 - J. Hampel, A gávai sírlelet. (Szabolcs m.), Archaeologiai Értesítő $31 / 2,1911,135-147$

Harhoiu 1997 - R, Harhoiu, Die frühe Völkerwanderungszeit in Rumänien, Archaeologia Romanica 1, Editura Enciclopedicâ, 1997.

Heras Mora, Olmedo Gragera 2015 - F. J. Heras Mora, A. B. Olmedo Gragera, Identidad y contexto en la necrópolis tardorromana de Mérida, in Quirós Castillo, J. A., Castellanos García, S. (eds), Identidad y etnicidad en Hispania. Propuestas teóricas y cultura material en los siglos V-VIII, Documentos de arqueología medieval 8, Bilbao Universidad del País Vasco, Servicio Editorial, 2015, 275-290

Horváth 2013 - E. Horváth, Gemstone and glass inlaid fine metalwork from the Carpathian basin: the Hunnic and Early Merovingian Periods, Dissertationes Archaeologicae ex Instituto Archaeologico Universitatis de Rolando Eötvös nominatae Ser. 3. No. 1, 2013, 275-302.

Horváth, Bendő, May 2013 - E. Horváth, Z. Bendő, Z. May, One Hundred years later ... Characteristics of materials technology and workshop affinities of the polychrome metalwork from Gáva (North-East Hungary), in Heinrich-Tamáska, O., Krohn, N., Ristow, S. (eds.), Macht des Goldes, Gold der Macht: Herrschaftsund Jenseitsrepräsentation zwischen Antike und Frühmittelalter im mittleren 
Donauraum. Akten des 23. Internationalen Symposiums der Grundprobleme der Frühgeschichtlichen Entwicklung im Mittleren Donauraum, Tengelic, 16. 19.11.2011, Forschungen zu Spätantike und Mittelalter 2, Verlag Bernhard Albert Greiner, 2013, 251-280.

Jósa 1910 - A. Jósa, A gávai gót lelet, Muzeumi és Könyvtári Értesítő 4, 1910, $226-230$

Храпунов 2002 - И. Н. Храпунов, Могильник Дружное (III-IV вв. нашей эры) / The cemetery of Droozhnoye (3rd-4th centuries), Monumenta Studia Gothica 2, Wydawnictwo Uniwersytetu Marii Curie-Skłodowskiej, 2002.

Khrapunov 2013a - I. Khrapunov, Several Results of the Researches of the Cemetery of Neyzats, in Khrapunov, I. (ed.), Exploring the Cemetery of Neyzats. Collected Papers, The Black Sea Archaeology in Translation 2, Dolya Publishing House, 2013, 13-123.

Khrapunov 2013b - I. Khrapunov, Die Nekropole von Družnoe, in Müller, S., Schmauder, M. (eds.), Die Krim. Goldene Insel im Schwarzen Meer. GriechenSkyten - Goten. Begleit-buchzur Ausstellung, LVR-LandesMuseum Bonn, 4. Juli 2013-19. Januar 2014, LVR-LandesMuseum Bonn, 332-339.

Храпунов 2018 - И. Н. Храпунов, Склеп с вещами в догуннском полихромном стиле из могильника Опушки, Крым в сарматскую епоху (II в. до н. е. - IV в. н.е.) 3, 2018, 137-169.

Храпунов, Стоянова 2018 - И. Н. Храпунов, А. А. Стоянова, Украшения в позднеримском полихромном стиле из могильника Опушки в Крыму, in О. В. Шаров (ed.), Terra Barbarica и «неримская элита», Stratum Plus. Археология и культурная антропология №4. 2018, Высшая антропологическая школа, 2018, 255-262.

Knific 1995 - T. Knific, Vojščaki iz mesta Karnija, in Kranjski zbornik 1995, Mestna občina Kranj, 1995, 23-40.

Knific, Lux 2010. - T. Knific, J. Lux, Otroci iz mesta Karnija, in Jenčič, B. (ed.), Jubilejni Kranjski zbornik 2010, Mestna občina Kranj, 2010, 26-36.

Knific, Lux 2015. - T. Knific, J. Lux, Kranj z okolico v pozni antiki - zapis geografa iz Ravene in arheološki podatki, in Jenčič, B. (ed.), Kranjski zbornik 2015, Mestna občina Kranj, 2015, 29-41.

Koch 2001 - U. Koch, Das alamannisch-fränkische Gräberfeld bei Pleidelsheim, Forschungen und Berichte zur Vor-und Frühgeschichte in Baden-Württemberg 60, Kommissionsverlag. Konrad Theiss Verlag, 2001.

Kubitschek 1911 - W. Kubitschek, Grabfunde in Untersiebenbrunn (auf dem Marchfeld), Jahrbuch für Altertumskunde 5 (1-3). K.K. Zentral-Kommission für Kunst- und historische Denkmale, 1911, 32-74.

Lăzărescu 2019 - V.-A. Lăzărescu, Debating the early phase of the Migration Period necropolis at Florești-Polus Center, Cluj County, Romania, in Tivadar, V., Quast, D., Rácz, Z., Koncz, I. (eds.), Kollaps - Neuordnung - Kontinuität / Collapse - Reorganization - Continuity: Gepiden nach dem Untergang des Hunnenreiches. Tagungsakten der Internationalen Konferenz an der Eötvös Loránd Universität, Budapest, 14. - 15. Dezember 2015 / Gepids after the fall of the Hun Empire. Proceedings of the International Conference at Eötvös Loránd University, Budapest, $14^{\text {th }}-15^{\text {th }}$ December 2015, Institut für Archäologiewissens chaften, Eötvös Loránd Universität, Budapest, Instituts für Archäologie des For schungszentrums für Humanwissenschaften der Ungarischen Akademie der W issenschaften, Budapest, Leibniz-Forschungsinstitut für Archäologie. RömischGermanische Zentralmuseum, Mainz, 2019, 81-110.

Lux, Ravnik 2008 - J. Lux, J. Ravnik, Poskus rekonstrukcije obsega poznoantičnega grobišča Lajh v Kranju / An Attempt to Reconstruct the Size of the Lajh Late Antiquity Cemetery in Kranj, Varstvo spomenikov 44, 2008, 43-69.

Manojlović-Marijanski 1964 - M. Manojlović-Marijanski, Kasnorimski šlemovi iz Berkasova, Posebna izdanja 3, Vojvođanski muzej u Novom Sadu, 1964.

Мастыкова 2018 - А.В. Мастыкова, Листовидные подвески эпохи Великого переселения народов в понто-кавказском регионе, Боспорские исследования 36 , 2018, 143-167.

Minguzzi 1983 - S. Minguzzi, Oreficeria, in Bermond Montanari, G. (ed.), Ravenna e il porto di Classe. Venti anni di ricerche archeologiche tra Ravenna e Classe, Realtà regionale. Fonte e Studi 7, University Press Bologna, 1983, 196-199.

Nagy, Rotea 2010 - S. Nagy, M. Rotea, 42. La tomba principesca di Florești, in Oberländer-Târnoveanu, E., Ungaro, L. (eds.), Ori antichi della Romania. Prima e dopo Traiano, SilvanaEditorale, 2010, 230-235.

Nagy, Rotea 2014 - S. Nagy, M. Rotea, 169. Piese din inventarul unui mormânt, Florești, jud. Cluj, in R. Oanțâ-Marghitu (ed.), Aurul și Argintul Antic al României.
Catalog de expoziție. Muzeul Național de Istorie a României, Editura Conphys, 2014, 637-640.

Oanță-Marghitu 2010 - R. Oanță-Marghitu, 40. La seconda tomba principesca di Apahida, in Oberländer-Târnoveanu, E., Ungaro, L. (eds.), Ori antichi della Romania. Prima e dopo Traiano, Silvana Editoriale, 2010, 222-225.

Oanță-Marghitu 2014 - R. Oanță-Marghitu, Metalele prețioase în antichitatea târzie și evul mediu timporiu, in Oanțâ-Marghitu R., (ed.), Aurul şi Argintul Antic al României. Catalog de expoziție. Muzeul Național de Istorie a României, Editura Conphys, 2014, 138-175.

Oanță-Marghitu, Nagy 2014 - R. Oanță-Marghitu, S. Nagy, Mormintele princiare de la Apahida, jud. Cluj, in Oanțâ-Marghitu, R. (ed.), Aurul și Argintul Antic al României. Catalog de expoziție. Muzeul Național de Istorie a României, Editura Conphys, 2014, 615-630.

Pavlovič 2017 - D. Pavlovič, Dragocenosti iz daljne Indije, in Miškec, A. (ed.), Preteklost pod mikroskopom. Naravoslovne raziskave $v$ muzeju, Narodni muzej Slovenije, 2017, 71-76.

Perko 2018 - V. Perko, Najdbe, ki so ponesle ime Kranja v svet, in Perko, V. (ed.), Nakit ostane. Dediščina, naš najdragocenejši nakit. Arheološki nakit iz Beograda, Tolmina, Brežic, Kranja in Kopra. Tatu, najbolj osebna oblika nakita, Gorenjski muzej, 2019, 85-119.

Pinar, Ripoll 2008 - J. Pinar, G. Ripoll, The so-called Vandal objects of Hispania in Berndt, G. M., Steinacher, R. (eds.), Das Reich Vandalen und seine (Vor-) Geschichte, Forschungen zur Geschichte des Mittelalters 13, Denkschriften der phil.-hist. Klasse 366, Verlag der Österreichischen Akademie der Wissenschaften, 2008, 105-130.

Quast 1993 - D. Quast, Die merowingerzeitlichen Grabfunde aus Gültlingen (Stadt Wildberg, Kreis Calw), Forschungen und Berichte zur Vor- und Frühgeschichte in Baden-Würtenberg 52, Kommissionsverlag. Konrad Theiss Verlag, 1993.

Quast 1996 - D. Quast, Schmuckstein- und Glasschnallen des 5. und frühen 6. Jahrhunderts aus dem östlichen Mittelmeergebiet und dem "sasanidenreich", Archäologische Korrespondenzblatt 26, 1996, 333-345.

Quast 2005 - D. Quast, Völkerwanderungszeitliche Frauengräber aus Hippo Regius (Annaba/Bône) in Algerien, Jahrbuch des Römisch-Germanischen Zentralmuseums Mainz 52/2, 2005, 237-315

Quast 2015 - D. Quast, Die Grabbeigaben - ein kommentierter Fundkatalog, in Quast, D. (ed.), Das Grab des fränkischen Königs Childerich in Tournai und die Anastasis Childerici von Jean-Jacques Chifflet aus dem Jahre 1655, Monographien des Römisch-Germanischen Zentralmuseums 129, Verlag des Römisch-Germanischen Zentralmuseums, 2015, 165-207.

Rácz, Koncz 2015 - Z. Rácz, I. Koncz, Kora középkori germán királyságok a Kárpát-medencében (5. sz. utolsó harmada - 6. sz. vége), - in Vágó, A. (ed.), A Kárpát-medence ősi kincsei. A kőkortól a honfoglalásig, Magyar Nemzeti Múzeum, Kossuth Kiadó, 2015, 397-431.

Schulze-Dörrlamm 2009-M. Schulze-Dörrlamm, Byzantinische Gürtenschnallen und Gürtelbeschläge im Römisch-Germanischen Zentralmuseum. Teil I. Die Schnallen ohne Beschläg, mit Laschenbeschläg und mit festem Beschläg des 5. bis 7. Jahrhunderts, Kataloge Vor- und Frühgeschichtlicher Altertümer 30/2, Verlag des Römisch-Germanischen Zenrtralmuseums, 2009.

Serra 1976 - P. B. Serra, Reperti tardoantichi e altomedievali dalla Nurra nel Muse Nazionale "G. A. Sanna" di Sassari, Quaderni 3, Ministero per i beni culturali e ambientali, Soprintendenza alle Antichitâ per le Provincie di Sassari e Nuoro. Collana diretta da F. Nicosia, 1976.

Slabe 2003 - M. Slabe, O pasnih sponah iz časa velikega preseljevanja ljudstev na Slovenskem (Okvirno 5.-6. stol. n. št.), in Jenčič, B., Globočnik, D., Rogelj, M., Lavrič, A., Zupan, G, Železnik, A. (eds.), 50 let Gorenjskega muzeja. Avguštinov zbornik. 1953-2003, Gorenjski kraji in ljudje 24, Gorenjski muzej, 2003, 82-90.

Stare 1980 - V. Stare, Kranj, nekropola iz časa preseljevanja ljudstev (s prispevkoma Zdenko Vinski, Ovrednotenje grobnih prodatkov in István Kiszely, Antropološki pogledi), Katalogi in monografije 18, Narodni muzej v Ljubljani, 1980.

Šmit et al. 2014 - Ž. Šmit, H. Fajfar, M. Jeršek, T. Knific, J. Lux 2014, Analysis of garnets from the archaeological sites in Slovenia, Nuclear Instruments and Methods in Physics Research B 328, 2014, 89-94.

Taramelli 1919 - A. Taramelli, XV. Dolianova (Cagliari) - Tombe di età della decadenza romana, con suppellettile ed orificerie, rinvenute in regione Su Bruncu e S'Olia, nell'agro dell'antica Dolia, Atti della R. Academia dei Lincei anno CCCXVI 1919, Serie quinta, Notizie degli scavi di antichità 16, 1919, 141-147. 
Tejral 1997 - J. Tejral, Neue Aspekte der frühvölkerwanderungszeitlichen Chronologie im Mitteldonauraum, in Tejral, J., Friesinger, H., Kazanski, M. (eds.) Neue Beiträge zur Erforschung der Spätantike im mittleren Donauraum, Spisy Archeologického ústavu AV ČR Brno 8, 1997, 321-392.

Tejral 2011 - J. Tejral, Einheimische und Fremde. Das norddanubische Gebiet zur Zeit der Völkerwanderung, Spisy Archeologického ústavu AV ČR v Brně, v.v.i. 33, Archäologisches Institut der Akademie der Wissenschaften der Tschechischen Republik Brno, v.v.i., 2011.

Tejral 2012 - J. Tejral, Cultural or ethnic changes? Continuity and discontinuity on the Middle Danube ca A.D. 500, in Ivanišević, V., Kazanski, M. (eds.), The Pontic-Danubian Realm in the Period of the Great Migration, Collège de France - CNRS. Centre de recherche d'historie et civilisation de Byzance, Monographies 36, Arheološki institut Beograd, Posebna izdanja 51, 2012, 115-188.

Tica 2017 - G. Tica, Goti med Jadranom in Panonijo, unpublished PhD thesis, Univerza na Primorskem, Fakulteta za humanistične študije, 2017.

Treister 2004 - M. Treister, Cloisonné- and champlevé-decoration in the gold work of the Late Hellenistic-Early Imperial periods, Acta Archaeologica 75/2, 2004, 189-219.
Urek et al. 2016 - M. Urek, T. Podobnik, Š. Tomažinčič, S. Djokić, Končno strokovno poročilo o arheoloških raziskavah grobišča $v$ Lajhu in prazgodovinske poselitve na območju Savske ceste in Sejmišča v Kranju (EŠD 5145, Kranj Arheološko najdišče Lajh; EŠD 274, Kranj - Mestno jedro), unpublished report, Magelan Skupina d.o.o., Kranj, 2016.

Vinski 1962 - Z. Vinski, O značaju nalaza seobe naroda iz Karavukova u Bačkoj, Vijesti muzealaca i konzervatora Hrvatske 11/3, 1962, 75-79.

Vinski 1970 - Z. Vinski, Obdobje preseljevanja narodov, in N. Miljković, N. (ed.), Umetnostni zakladi Jugoslavije, Izdavački zavod Jugoslavija, Državna založba Slovenije, 1970, 143-162.

Яценко, Малашев 2000 - С. А. Яценко, В. Ю. Малашев, О полихромном стиле позднеримского времени на территории Сарматии, in Ерёменко, В. Е., Смирнова, Г. И., Шаров, О. В., Щукин, М. Б. (eds.), Время великих миграций, Stratum Plus. Культурная антропология и археология №4. 2000, Высшая антропологическая школа, 2000, 226-250.

Засецкая1994 - И. П. Засецкая, Культура кочевников южнорусских степей ө гуннскую эпоху (конец IV-V вв.), Эллипс. лтД, 1994 